\title{
Determinants of Lending Interest Rates of Nepalese Commercial Banks
}

\author{
Yuga Raj Bhattarai, Ph.D
}

\begin{abstract}
The aim of this study is to investigate the determinants of lending rate of Nepalese commercial banks. The analysis of data was based on a sample of 6 commercial banks observed over the period 6 years (2010 to 2015). The models used in the study were: pooled OLS model, fixed effects model and random effects model. This study has used 'lending rate' as dependent variable, while the explanatory variables are: operating cost to total assets ratio, deposit interest rate, profitability (ROA) and default risk. The estimated results of these three regression models reveal that operating costs to total assets ratio, profitability (ROA) and default risk have significant positive impact on the commercial bank lending rate. However, deposit rate has negligible impact on lending interest rate. Thus, this study concludes that the major determinants of commercial banks' lending rate are: operating costs to total assets ratio, profitability (ROA) and default risk in Nepalese perspectives.
\end{abstract}

Keywords: bank, lending interest rates, deposit rate, return on assets, credit risk

\section{INTRODUCTION}

Interest rate is one of the important terms in the lending decision process of commercial banks. Commercial banks are independent business entities that set their own lending rates. The lending interest rate is the percentage of the loan amount that the lender charges to lend money. When banks lend money to customers, interest is charged on it for a number of reasons, including value preservation, compensation for risk, and profits among others (Sheriff \& Amoako, 2014).

Commercial banks can increase their profit margins through higher lending rates and lower deposit rates. Banks do not charge loan rates that are too low because the revenue from the interest income will not be enough to cover the cost of deposits, general expenses and the loss of revenue from non-performing loan portfolio. On the other hand, they cannot charge too high loan rates because they will not be able to keep the banking relationship with the borrowers with high lending rate. Thus, determination of the appropriate lending rates usually becomes a major issue in banking industry. Moreover, the factors that determine the level of commercial banks' lending rates are

1 Dr. Bhattarai is an Associate Professor at Patan Multiple Campus, Tribhuvan University. He can be reached at yugarajbhattarai@gmail.com 
important concerns not only for specific banks but also to policy makers, the banking industry and the public at large.

Lending interest rate of commercial banks may be influenced by a number of factors. The classical theory argues that the rate of interest is determined by two forces. Firstly the supplies of savings, derived mainly from households, and second the demand for investable capital, coming mainly from the business sector (Rose, 2003). Moreover, the loanable funds theory considers the rate of interest as the function of four variables: savings, investment, the desire to hoard money and supply of money. Rational expectation theory posits that the best estimation for future interest rates is the current spot rate and that changes in interest rates are primarily due to unexpected information and or changes in economic factors (Irungu, 2013).

Thompson (2006) asserts that banks may well set their lending rate according to a certain "mark-up" relative to the deposit rate. Accordingly, one of the important factors determining lending interest rate may be considered as the cost of funding, which is a function of the composition of liabilities and the costs of raising the different liabilities. Diebold and Sharpe (1990) and Hutchison (1995) assert that policymakers announce that there is to be an adjustment to the interest rate, banks may actually adjust their lending rates asymmetrically; that is, there may be a tendency for them to raise their lending rates much more rapidly when market interest rates are rising, as compared to the speed at which they are prepared to lower their lending rates when the market rate is declining.

Likely, other factors affecting lending interest rates include pricing for different types of risk ( such as the credit risk associated with the loan and the liquidity risk involved in funding long-term assets with short-term liabilities) and choices about growth strategies in different markets. The level of the cash rate set by the central bank is a primary determinant of the level of intermediaries' funding costs and hence, the level of lending rates. Moreover, an increaseof lending interest rates may be provoked by the following factors alternatively or cumulatively: an anti-inflationary policy of the central bank, a policy by the central bank aimed at revaluating the currency or defending it from devaluation, an attempt of the Treasure of covering public deficit by issuing more bonds in an unwilling market, and an attempt of banks of widening their margins.

Additionally, lending interest rate of commercial banks may be influenced by operating cost to total assets ratio, deposit rate, profitability and default risk. The term of a loan can have an influence on the interest rate charged. Short-term interest rates usually apply to money lent for a period of one year or less. Long-term interest rates can be 
either higher or lower than short-term rates, depending on the term of the loan and the prospects for economic growth and inflation. In general, long-term interest rates reflect the expected level of short-term rates plus a risk premium to compensate for uncertainty. This premium tends to increase with the term of the loan because the uncertainty increases as one goes further into the future.

In general, empirical studies that examine the determination of bank lending interest rate use variables that basically fall in three categories: (i) individual bank-specific factors such as operating or administrative costs, non-performing loans, return on assets, structure of the balance sheet, non-interest income or non-core revenues, bank size, bank liquidity, among others; (ii) factors specific to the banking sector/industry such as the degree of competition or market concentration, regulatory requirements such as statutory reserve requirements or regulated minimum deposit rates and, (iii) macroeconomic indicators which include real gross domestic product (GDP) growth rate and inflation rate. Some studies focus on one category of factors while others consider two or all the three categories of factors.

Determinants of lending interest rate in commercial bank have often been a subject of heated debate in Nepal. The main concern of debate is that the price of loans of Nepalese commercial banks was relatively high for a long period, thus limiting access to capital and inhibiting economic growth. A comparison of the trends in the lending rate shows that a much greater range is invariably found for increases in the lending rate than for reductions. Although there has been a trend towards lower lending rates and narrower spreads in recent years, they are still relatively high. However, the achievement to reduce lending rates will depend on how banks determine the interest rates that they charge.

Banking industry in Nepal is still growing and it should ensure that effective strategies are put in place to minimize lending interest rate. Moreover, the interest rates charged on lending by commercial banks have been a sensitive and recurring policy issue in Nepal and one which requires an objective examination of all the factors that influence commercial banks' lending interest rates. This study is the first empirical analysis to investigate the determinants of lending rates in commercial banks Nepal. The objective of this study is to investigate factors that influence lending interest rates in Nepalese commercial banks. However, this study is only concentrated on the individual bankspecific factors to include in the analysis. The results of this study may enable bank executives understand the factors affecting the lending interest rate and they may then make decision to set appropriate lending interest rate. The findings of this study may help guide policymakers to better obtain the objective of reducing the cost of borrowing. 
The remainder of the study is outlined as follows: section two reviews related literature, section three contains an explanation of research methodology used, section four focuses on results and discussion, section five presents the conclusion and section six incorporates policy recommendations.

\section{LITERATURE REVIEW}

The empirical literature indicates that factors that influence interest rate setting by commercial banks can be classified in three categories: bank-specific factors; factors specific to the banking industry; and broader macroeconomic factors. A wide range of different variables have been identified as important within each of these categories (Grenade, 2007; Olokoyo 2011; Cihak, 2004; Georgievska et al., 2011). At the level of individual banks or the banking industry, these include variables such as market power and levels of operating costs, provisions, and liquidity in relation to bank assets. More specifically, it has been well established that banks tend to, at least in part, pass on costs associated with higher taxes or non-performing loans (Chodechai, 2004; Chirwa \& Mlachila, 2004; Georgievska et al., 2011; Siddique, 2012; Were \& Wambua, 2013). Moreover, unsurprisingly, at the macroeconomic level, variables such as inflation and the pace of economic growth have been found to matter.

Schnitzel (1986) has examined the causation between deposit rates and mortgage loan rates through empirical tests. The author asserts that loan interest rates have been affected by deposit interest rates for the period under the regulated deposit interest rate regime. A study related to Croatia comes from Cihak (2004) who investigated the determinants of lending rates and interest rate spreads in Croatia between 1999 and 2003. The author based on the results of this panel estimation finds an inverse relation between lending rates and interest rate spreads, on the one hand, and bank size (total assets), liquidity and foreign ownership, on the other. In addition, the author also finds that market share, non-performing loans, deposit rates and money market rates have a positive effect on lending rates and interest rate spreads. Capital adequacy has a different effect on lending rates from the one on spreads. According to the author, banks with higher capital adequacy have lower lending rates, but they have even lower deposit rates, so that their spreads are higher than in banks with lower capital adequacy.

Gambacorta (2008) has investigated the way how banks determine their interest rates. Using two lags in the model estimations, the author has sampled 73 cross-sections that are the banks operating across Italy. The scholar shows that the factors such as interest rate volatility, bank efficiency, credit, and interest risks as well as temporary 
and permanent changes in income have all significant impacts on the level of bank interest rates.

Georgievska, Kabashi, Trajkovska, Mitreska and Vaskov (2011) have examined determinants of lending rates and interest rate spread in Greece. The data used for this study was for the period 2001 to 2009. Panel estimation methods were used to analyze the data, and the results from their study indicate that lending rates are mostly influenced by bank size and share and to a lesser extent by deposit rates and non-performing loans.

Mbao, Kapembwa, Mooka, Rasmussen and Sichalwe (2014) have examined the determinants of bank lending rates in Zambia. The authors have employed panel regression techniques using detailed bank-specific data that reflect a wide range of cost and income determinants for banks. Their results indicate that lending rates are to a significant extent influenced by variables relating to banks' costs. They found that inflation has significant impact on nominal interest rates on an almost one-to-one basis. Apart from inflation, however, elements of banks' balance sheet reveal that lending rates are to a significant extent also positively impacted by variables associated with higher cost structures or lower income.

Simpasa et al. (2014) have used bank-specific data but focused on how these data influence the volume of lending and did not specifically look at lending rates. Nevertheless, that study's finding that monetary policy has a strong impact on lending behavior of large commercial banks would be consistent with a significant impact on lending rates too.

Matemilola, Bany-Ariffin and Muhtar (2015) have investigated the long-run interest rate pass-through of the money market rate to the bank lending rate and asymmetric adjustment of the bank lending rate. The authors have applied the momentum threshold autoregressive and asymmetric error correction models. Results of the analysis reveal that bank lending rate adjusts to a decrease in the money market rate in South Africa. Their findings suggest that the South African commercial banks adjust their lending rate downward but the lending rate appears rigid upward, which supports the customer reaction hypothesis.

Literature informs that lending interest rate is determined by a variety of factors such as: bank-specific factors; factors specific to the banking industry; and macroeconomic factors. While the literature focus on the determinants of the commercial banks' lending interest rate such as: operating cost to total assets ratio, deposit rate, profitability and 
default risk in different perspectives, however, a study focusing on such issue have not yet been conducted in Nepal. Therefore, this study intends to fill this gap.

\section{RESEARCH METHODOLOGY}

\section{The Sample and Data}

The data used in this study to find determinants of lending interest rates of Nepalese commercial banks comes from six commercial banks over the period of 6 years (20102015). This study has adopted descriptive and causal comparative research design. The convenience sampling method was used in choosing the banks for the study. Moreover, in selecting the 6 banks for the study, due care is given to include banks such as: joint venture, domestic, best performer, average performer and comparatively week performer in the sample. The banks selected for the study are: Global IME Bank Ltd., Everest Bank Ltd., Kumari Bank Ltd., Nepal Investment Bank Ltd., Laxmi Bank Ltd. and Nabil Bank Ltd.. The population of this study is the "A class" commercial banks listed in the Nepal Stock Exchange (NEPSE). This study assumes that the selected samples fairly represent the study population. Data were collected from the annual reports of the banks in the sample.

\section{Estimation Strategy}

As the data used in this study are pooled in nature, the estimation is not limited to the use of ordinary least squares (OLS) method only. According to Greene (2007) the models for panel data can be arranged as: pooled regression, fixed effects, random effects and random parameters. In practice, panel data models are estimated using pooled OLS, fixed effects or random effects techniques (Mujeri \& Younus, 2009). Onuonga (2014) asserts that if the assumption holds that the unobservable individual bank-specific effects are not very different, pooled OLS estimations is the most simple and efficient method for panel data analysis. However, Cottrell and Lucchetti (2017) stress that in most cases this is unlikely to be adequate, but it provides a baseline for comparison with more complex estimators. Moreover, Cottrell and Lucchetti (2017) have pointed out that the choice of panel method also depends on the nature of the data set. If the panel compares observations on a fixed and relatively small set of units of interest (say, banks), there is a presumption in favor of fixed effects. If it compares observations on a large numbers of randomly selected individuals unit (say, banks), there is a presumption in favor of random effects.

In this study, the use of Gretl software has facilitated the test of the panel model. When one estimates a model using fixed effects, the Gretl software can provide an F-test for the null hypothesis that the cross-sectional units all have a common intercepts. That 
is to say that all the $\alpha_{\mathrm{i}} \mathrm{s}$ are equal, in which case the pooled model is adequate. When anyone estimates using random effects, the Breusch-Pagan and Hausman tests may be used. In this case, the Breusch-Pagan test is taken as the counterpart to the F-test. The null hypothesis is that the variance of $v_{i}$ in the given equation equals zero; if this hypothesis is not rejected, then again one can conclude that the simple pooled model is adequate.

Further, the choice between a fixed effects (FE) and random effects (RE) model is also guided by certain test statistics. Baltagi, Bresson and Pirotte (2003) emphasized that most applications in economics since the 1980s have made the choice between the RE and FE estimators based upon the standard Hausman test. The authors suggest that if this standard Hausman test rejects the null hypothesis that the conditional mean of the disturbances given the regressors is zero, the applied researcher reports the FE estimator, otherwise, the researcher reports the RE estimator. Likewise, Gujarati (2004) has asserted that as a formal test, Hausman test can be used to decide between fixed effect models (FEM) and random effect model (REM) for panel data analysis. According to Gujarati (2004), the null hypothesis underlying the Hausman test is that the FEM and REM estimators do not differ substantially. The author insisted that if null hypothesis is rejected, the conclusion is that REM is not appropriate and that the researcher may be better off using FEM. Moreover, using Hausman test, if the p-value is greater than $5 \%$, the random effects do not appear to be correlated with the regressors and random effects model can be used.

In line with these theoretical scenarios, this study has estimated these three models into panel data set of the banks in the sample. Since, Nepalese commercial banks have unique characteristics that are both un-measurable and constant overtime; pooled OLS estimations may not be adequate model for the data. Thus, this study has further estimated fixed effects and random effect models in the data analysis procedures. In this study, data analysis was done using the Gretl Version 1.1.

\section{The model}

This study has used three econometric models for identifying the determinants of the lending interest rates of Nepalese commercial banks. The simplest, and possibly naïve, approach is to disregard the space and time dimensions of pooled data and just estimate the usual OLS regression (Gujarati, 2004). Similarly, Cottrell and Lucchetti (2017) assert that the simplest estimation for panel data is pooled OLS. Thus, initially pooled OLS model has been estimated in the study. The pooled OLS model is:

$\mathrm{Y}_{\mathrm{it}}=\alpha+\beta \mathrm{X}_{\mathrm{it}}+\varepsilon_{\mathrm{it}}$ 
Where,

$\mathrm{Y}$ is the dependent variable; $\alpha$ is constant; $\beta$ is the coefficient of explanatory variables; $X_{i t}$ is the vector of explanatory variables; and $\varepsilon_{i t}$ is the error term (assumed to have zero mean and independent across the time period).

Based on the prescribed econometric model, the regression equation for determinants of lending interest rates of commercial banks is specified as:

$\mathrm{LIR}_{\mathrm{it}}=\beta_{0}+\beta_{1} \mathrm{OCTA}_{\mathrm{it}}+\beta_{2} \mathrm{DIR}_{\mathrm{it}}+\beta_{3} \mathrm{PROF}_{\mathrm{it}}+\beta_{4} \mathrm{DR}_{\mathrm{it}}+\mathrm{e}_{\mathrm{it}}$

Where:

$\operatorname{LIR}_{i t}=$ Lending interest rate of $\mathrm{i}^{\text {th }}$ bank in year $\mathrm{t}$

OCTA $_{\text {it }}=$ Operating cost to total assets ratio of $i^{\text {th }}$ bank in year $t$

$\mathrm{DIR}_{\mathrm{it}}=$ Deposit interest rate, which is the average interest rate on deposits of $\mathrm{i}^{\text {th }}$ bank in year $\mathrm{t}$

$\mathrm{PROF}_{\mathrm{it}}=$ Profitability, which is calculated as net income divided by total assets of $\mathrm{i}^{\text {th }}$ bank in year $\mathrm{t}$

$\mathrm{DR}_{\mathrm{it}}=$ Default risk, which is calculated as non-performing loans to total loans of $\mathrm{i}^{\text {th }}$ bank in year $\mathrm{t}$

$\beta_{0}=$ The intercept of the regression line

$\beta_{1}, \beta_{2}, \beta_{3}, \beta_{4}=$ The slope which represents the degree with which lending interest rates changes as the independent variable changes by one unit variable. The priori expectation is that the coefficients $\beta_{1,} \beta_{2}$ and $\beta_{4}>0$, while $\beta_{3}<0$.

$\mathrm{e}_{\mathrm{it}}=$ error component

Pooled OLS model assumes $\alpha$ and $\beta$ are the same for every bank. In practice, $\alpha$ (and sometimes $\beta$ ) are different for different banks and occasionally the model seems inadequate to derive precise conclusion. Therefore, additionally fixed effects model and random effect model have been employed in the study for better estimation. Cottrell and Lucchetti (2017) state that the fixed and random effects models have in common that they decompose the unitary pooled error term, $\mathrm{u}_{\mathrm{it}}$. However, the fixed effects estimations allow for the unobservable bank heterogeneity. Fixed effects model uses dummy variables to model the individual bank effect, meaning that each individual bank has different intercept. In this model, the intercepts for each bank are allowed to vary, but the slopes for each bank are equal. In this instance, Greene (2007) has suggested the following fixed effect model: 
$Y_{i t}=X_{i t} \beta+\alpha_{i}+\varepsilon_{i t}$

Where, $\alpha_{i=} z_{i} \alpha$, embodies all the observable effects and specifies an estimable conditional mean. Greene (2007) assets that fixed effect approach takes $\alpha_{i}$ to be a group-specific constant term in the regression model. The author indicates that each $\alpha_{i}$ is treated as an unknown parameter to be estimated. Thus, the fixed effects formulation implies that differences across groups can be captured in differences in the constant term.

In some cases, fixed effects estimations become less efficient than random effects estimations. The rationale behind random effects model is that, unlike the fixed effects model, the variation across entities is assumed to be random and uncorrelated with the predictor or independent variables included in the model. Random effects estimations take into consideration the unobservable bank heterogeneity effects, but incorporate these effects into the error terms, which are assumed to be uncorrelated with the explanatory variables. In similar way, Greene (2007) pointed out that if the unobserved individual heterogeneity, however, formulated, can be assumed to be uncorrelated with the included variables, then the model may be formulated in random effect form. The random effect model suggested by Greene (2007) can be written as:

$Y_{i t}=X_{i t} \beta+\alpha+u_{i}+\varepsilon_{i t}$

According to Greene (2007) this random effects approach specifies that $u$ isa group specific random element, similar to $\varepsilon_{i t}$ except that for each group, there is but a single draw that enters the regression identically in each period. However, the $\varepsilon_{\mathrm{it}}$ represents within entity error. Moreover, Greene (2007) specifies that the crucial distinction between fixed and random effects is whether the unobserved individual effect embodies elements that are correlated with the regressors in the model, not whether these effects are stochastic or not.

In view of these selected models, the collected panel data have been analyzed to assess the determinants of lending interest rates in Nepalese context.

\section{Variables and Hypotheses}

The choice of variables in this study was mostly affected by the approach in other empirical studies, as well as by determinants suggested by the literature. The factors affecting lending rates were examined by defining a set of variables which are directly related to bank balance sheets and bank characteristics.

\section{Dependent variable}

The dependent variable in this study is the lending interest rate (LIR).It is the average interest rate on lending of commercial banks. Lending rate is the price that a borrower 
paid when taking loans from the commercial banks. It is hypothesized that lending interest rate of commercial banks is influenced by operating cost to total assets ratio, deposit interest rate, profitability and default risk.

\section{Independent variables}

The independent variables used in identifying the determinants of LIR are the following:

Operating cost to total assets ratio (OCTA): Operating cost to total assets ratio has been considered as one of the independent variable in this study. The ratio of operating expenses to total assets measures the cost required to provide a loan unit, and depends on the productivity of staff and other operating costs (administrative burdens, branch network, transport, depreciation, etc.). The key indicator of efficiency of commercial bank is the ratio of operating costs to total assets. The lower the ratio is, the higher the efficiency of the commercial banks. Moreover, high operating costs are likely to include costs due to inefficiency leading to higher lending interest rate and hence this variable is commonly used as an indicator of operational inefficiency. However, commercial banks can lower their lending rates in order to remain competitive by reducing operating costs. Thus, operating expense to total assets ratios may be considered as the determining factor in lending rates. Mbao, Kapembwa, Mooka, Rasmussen and Sichalwe (2014) also found that operating costs has positive effect on lending rates. In line with theory and past empirical evidence, an increase in operating costs is expected to have positive influence on lending interest rate.

Hypothesis $H_{1}$ : Operating cost to total assets ratio has a significant and positive effect on lending interest rate.

Deposit interest rate (DIR): Deposit interest rate is the average interest rate on retail deposits at each bank (in percent). The interest paid on customer deposits depends on deposit interest rates. Lending interest rate can increase with increasing deposit interest rate. Schnitzel (1986) examines the causation between deposit rates and mortgage loan rates through empirical tests. The author shows that loan interest rates have been affected by deposit interest rates for the period under the regulated deposit interest rate regime. Kaymaz and Kaymaz (2011) have obtained strong evidence of one-way causality between loan interest rates and deposit interest rates. They asserted that in setting their loan interest rates, banks use deposit interest rates of the preceding period. They found significant positive correlation between loan interest rates and deposit interest rates. Mbao, Kapembwa, Mooka, Rasmussen and Sichalwe (2014) 
found that interest rate paid on deposits has significantly positive effect on lending rates. The positive relationship is expected between lending rates and deposit interest rate.

Hypothesis $\mathrm{H}_{2}$ : Deposit interest rate has a significant and positive effect on lending interest rate.

Profitability (PROF): Profitability is computed as net income divided by total assets. This is generally considered as a good indicator to evaluate the profitability of the assets of a bank in comparison to other banks in the banking industry. Mbao, Kapembwa, Mooka, Rasmussen and Sichalwe (2014) found negative association between lending rates and profitability (return on assets). They asserted that increases in bank costs tend to be passed on to borrowers in the form of higher lending rates, and that factors that help improve bank income also tend to benefit borrowers by lowering the interest rates they pay. A negative relationship is expected between lending interest rate and profitability. It is hypothesized that return on average assets influences banks' lending rates and also banks with high return on average assets offer lower interest rates on loans.

Hypothesis $\mathrm{H}_{3}$ : Profitability has a significant and negative effect on lending interest rate.

Default risk (DR): Lending interest rates are also affected by the likelihood a borrower may fail to repay some or even all of a loan's principal and interest. This possibility of default may be related to a change in the financial health or condition of the borrower brought about by normal as well as unexpected swings in the overall level of economic activity. Default rate on total loan and advances is proxied by non-performing loan ratio. Non-performing loan is also another variable which affect lending rate, this variable is measured as the ratio of the total loan or non-performing loans to total loans. An increase in the provision for loan losses implies a higher cost of bad debt write-offs. Given the risk-averse behaviour, banks face higher credit risk is likely to pass the risk premium to the borrowers, leading to higher borrowing rate. This variable expected to have a positive relationship with lending rate.Non-performing loan is also another variable which affect lending rate, this variable is measured as the ratio of the total loan or non-performing loans to total loans. Mbao, Kapembwa, Mooka, Rasmussen and Sichalwe (2014) also found positive association between lending rates and NPL ratio, meaning that increase in the NPL ratio produces increase in the lending rate. An increase in the provision for loan losses implies a higher cost of bad debt write-offs. Given the risk-averse behaviour, banks face higher credit risk is likely to pass the risk 
premium to the borrowers, leading to higher borrowing rate. This variable expected to have a positive relationship with lending rate.

Hypothesis $H_{4}$ : Default risk has a significant and positive effect on lending interest rate.

\section{RESULTS AND DISCUSSION}

\section{Descriptive Statistics}

The descriptive statistics of the variables used in the study are presented in Table 1. The result shows that the minimum and maximum lending rates of Nepalese commercial banks during the sample period are $7.83 \%$ and $15.37 \%$ respectively. The average lending rate is $11.21 \%$ meaning that Nepalese commercial banks charge, in average, $11.21 \%$ annual interest on their loans and advances.

Table 1: Descriptive Statistics of Variables $(n=36)$

\begin{tabular}{lccllllll}
\hline Variables & Scale & Mean & $\begin{array}{l}\text { Std. } \\
\text { Deviation }\end{array}$ & Minimum & Maximum & CV & Skewness & $\begin{array}{l}\text { Ex. } \\
\text { kurtosis }\end{array}$ \\
\hline LIR & $\%$ & 11.211 & 1.709 & 7.830 & 15.370 & 0.152 & 0.134 & -0.452 \\
OCTA & $\%$ & 6.817 & 2.218 & 3.242 & 15.312 & 0.325 & 1.403 & 4.169 \\
DIR & $\%$ & 5.841 & 1.581 & 2.520 & 8.880 & 0.271 & -0.056 & -0.865 \\
PROF & $\%$ & 2.707 & 2.588 & 0.424 & 9.693 & 0.956 & 1.734 & 1.368 \\
DR & $\%$ & 1.558 & 0.918 & 0.120 & 4.030 & 0.589 & 0.529 & -0.128 \\
\hline
\end{tabular}

Source: Annual report of sample banks and results are drawn from Gretl

The key indicator of efficiency is the ratio of operating costs to total assets and the results of operating costs to total assets ranged from $3.24 \%$ in the most efficient to $15.31 \%$ at the other extreme.The average operating cost to total assets ratio is $6.82 \%$ and the standard deviation of the same variable is $2.22 \%$. The result shows that Nepalese commercial banks are incurring high operating costs which are leading to higher lending interest rate. Moreover, the operating cost is found more volatile during sample period. The average deposit rate is $5.84 \%$, meaning that in average Nepalese commercial banks offer about one half of the lending rate on the customers' deposits, which looks low. The prevailing deposit interest rates are not found attractive to customer deposits. 
The average profitability (ROA) is $2.71 \%$, which shows the weak profitability position of Nepalese commercial banks. However, the standard deviation of the profitability (ROA) is $2.59 \%$. The standard deviation looks highest as compared to other variables used in this study and it indicates the substantial variation of profitability during sample period. There is also low variation among the banks default risk which is evident from low standard deviation of the default risk variable, which is 0.918 .

\section{Correlation analysis}

The correlation coefficients among study variables are shown in Table 2.

Table 2: Pearson Correlations $(\mathrm{n}=36)$

\begin{tabular}{llllll}
\hline LIR & OCTA & DIR & PROF & DR & Variables \\
\hline 1.0000 & 0.7473 & 0.5780 & 0.0984 & 0.1753 & LI R \\
& 1.0000 & 0.6019 & -0.1577 & 0.1239 & OCTA \\
& & 1.0000 & -0.1808 & 0.1247 & DIR \\
& & 1.0000 & -0.0048 & PROF \\
& & & 1.0000 & DR \\
\hline
\end{tabular}

Correlation coefficients are drawn from Gretl

Results indicate that bank lending rate is significantly positively correlated with operating costs to total assets ratio and deposit rate, meaning that these two variables may significantly affect lending rate of Nepalese commercial banks. Moreover, this implies that the bank lending rate tends to move in the same direction with operating costs to total assets ratio and deposit rate.

Although, the lending rate is positively correlated with profitability and default risk but coefficients are statistically insignificant. The results imply that the relationships are not strong. Moreover, the correlation matrix of the variables presented Table 2 reveals that all correlations coefficients among the independent variables are less than 0.61 , implying the absence of multicollinearity. Thus, there is no evidence of presence of multicollinearity among the independent variables.

\section{Regression Results}

Initially, the model diagnostic test has been conducted to choose appropriate model in the current study. The result of model diagnostic test has been presented in Table 3 . 
Table 3: Model Diagnostic Test

\begin{tabular}{llll}
\hline Model comparison & $\begin{array}{l}\text { Joint significance } \\
\text { of differing } \\
\text { group means' test }\end{array}$ & $\begin{array}{l}\text { Breusch-Pagan } \\
\text { test statistic }\end{array}$ & $\begin{array}{l}\text { Hausman test } \\
\text { statistic }\end{array}$ \\
\hline
\end{tabular}

Compare pooled

OLS model with

fixed effect model.

F-statistics F 8.2467

$(5,26)$

$\mathrm{p}$-value

\subsection{4e-005}

Decision

Reject Pooled

OLS and choose fixed effects model
Compare pooled

OLS

model with random effect model
Chi-square

(1)

$\mathrm{p}$-value

Decision

\subsection{6}

0.0523

Choose pooled OLS model instead of random effect model

Chi-square

21.8955

Compare random

(4)

effect model with fixed effect model

$\mathrm{p}$-value

0.0002

Decision

Choose fixed effect model and reject random effect model.

The diagnostic test starts with the use of 'Joint significance of differing group means' test to compare pooled OLS model with fixed effect model. The results of F statistics $\mathrm{F}(5,26)=8.2467$ with $\mathrm{p}$-value $8.98294 \mathrm{e}-005$ rejects the null hypothesis that the pooled OLS model is adequate. The general rule is that a low p-value counts against the null hypothesis that the pooled OLS model is adequate, in favor of the fixed effect alternative. Since, in this study, the p-value is less than 0.05 , the fixed effect model stood superior to that of pooled OLS model. Again in order to compare the pooled OLS model with random effect model, Breusch-Pagan test statistic has been used. The test result $\mathrm{LM}=3.766$ with $\mathrm{p}$-value $=$ prob $($ Chi-square $(1)>3.766)=0.052$ supports that 
pooled OLS model is adequate because p-value of chi-square is slightly higher than 0.05. The general rule is that a low p-value count against the null hypothesis that pooled OLS model is adequate, in favor of the random effects model. The results of Breusch-Pagan test statistic recommends pooled OLS model instead of random effect model for the current study.

Moreover, in order to compare the random effect model with fixed effect model, Hausman test statistic has been used. The results of Hausman test statistic $\mathrm{H}=21.8955$ with $p$-value $=$ prob $($ chi-square $(4)>21.8955)=0.0002$ indicate that fixed effect model is preferred instead of random effect model. The general rule is that a low p-value counts against the null hypothesis that the random effects model is consistent, in favor of the fixed effects model. In view of the model diagnostic test statistics, fixed effects model seems appropriate and best model to be used in the current study among three alternative models employed. However, the results of the three models are presented and discussed in order to arrive at better conclusion.

The test for normality of residual has been conducted in the current study using Gretl and the test statistics have been presented in Table 4.

Table 4: Test Statistics for Normality

\begin{tabular}{lllll}
\hline Statistics & & $\begin{array}{l}\text { Pooled OLS } \\
\text { Model }\end{array}$ & $\begin{array}{l}\text { Fixed Effect } \\
\text { Model }\end{array}$ & $\begin{array}{l}\text { Random } \\
\text { Effect Model }\end{array}$ \\
\hline $\begin{array}{l}\text { Test Statistics for } \\
\text { normality }\end{array}$ & Chi-square (2) & 0.173 & 0.0404 & 0.79488 \\
& p-value & 0.9171 & 0.81714 & 0.672038 \\
\hline
\end{tabular}

In pooled OLS model, the result of the test for null hypothesis of normal distribution: Chi-square $(2)=0.173$ with p-value 0.9171 shows that null hypothesis is accepted. Thus, panel data set used in pooled OLS model is normally distributed. In fixed effect model, the test for normality of residual was performed. The null hypothesis was that error is normally distributed. The result of the test statistics is Chi-square $(2)=0.4039$ with $\mathrm{p}$-value $=0.8171$. The insignificance $\mathrm{p}$-value of Chi-square indicates that the null hypothesis is accepted that error is normally distributed.

The test for normality of residual has also been conducted for random-effects model. The null hypothesis was that error is normally distributed. The result of test statistic is Chi-square $(2)=0.7949$ with $p$-value $=0.6720$. The insignificant $p$-value of Chi-square (2) test statistic indicates that the null hypothesis is accepted. The result proves that error is normally distributed. The results of the three regression models employed in the study are presented in Table 5. 
Table 5: Regression Coefficients $(\mathrm{n}=36)$

\begin{tabular}{|c|c|c|c|c|c|c|c|c|c|c|}
\hline \multirow[t]{2}{*}{ Variables } & \multicolumn{4}{|c|}{ Pooled OLS Model } & \multicolumn{3}{|c|}{ Fixed Effect Model } & \multicolumn{3}{|c|}{ Random Effect Model } \\
\hline & Coefficients & $\mathrm{t}$ & Sig. & VIF & Coefficients & $\mathrm{t}$ & Sig. & Coefficients & $\mathrm{t}$ & Sig. \\
\hline Constant & 5.781 & 7.011 & 0.000 & & 8.929 & 11.54 & 0.000 & 7.482 & 8.882 & 0.000 \\
\hline OCTA & $0.493^{* *}$ & 4.756 & 0.000 & 1.580 & 0.229 & 2.542 & 0.017 & 0.365 & 3.817 & 0.0001 \\
\hline DIR & 0.247 & 1.689 & 0.101 & 1.594 & -0.0064 & -0.059 & 0.954 & 0.107 & 0.862 & 0.395 \\
\hline PROF & $0.159^{*}$ & 2.209 & 0.035 & 1.038 & 0.0713 & 1.393 & 0.176 & 0.112 & 1.892 & 0.068 \\
\hline \multirow[t]{2}{*}{ DR } & 0.128 & 0.637 & 0.529 & 1.020 & 0.3626 & 2.035 & 0.052 & 0.204 & 1.070 & 0.293 \\
\hline & \multicolumn{4}{|c|}{$\begin{array}{l}\mathrm{R}^{2}=0.6454, \quad \text { Adj. } \mathrm{R}^{2}=0.5996, \\
\mathrm{~F} .=14.1034, \mathrm{P} \text {-value }(\mathrm{F})=0.0000 \\
\text { White's test for heteroskedasticity } \\
\text { Test statistic: } \\
\mathrm{TR}^{\wedge} 2(\mathrm{Chi} \text {-square }(14)) \\
=11.8052, \\
\text { P-value }=0.6219, \\
\text { Chow test for structural break at } \\
\text { observation } 3: 6: \\
\mathrm{F}(5,26)=1.2594, \\
\text { P-value }=0.3110, \\
\text { Durbin-Watson statistic }=1.2672, \\
\text { P-value }(\mathrm{DW})=0.0683\end{array}$} & \multicolumn{3}{|c|}{$\begin{array}{l}\mathrm{R}^{2}=0.8629, \quad \text { Adj. } \mathrm{R}^{2}= \\
0.8154 \\
\mathrm{~F}(9,26)=18.1760, \\
\text { P-value }(\mathrm{F})=0.0000, \\
\text { Durbin-Watson }=1.9637, \\
\text { P-value }(\mathrm{DW})=0.4744 \\
\text { Test for differing group } \\
\text { intercepts-Test statistic: } \\
\quad \mathrm{F}(5,26)=8.2467, \\
\text { p-value }=0.0000 \\
\text { Wald test for } \\
\text { heteroskedasticity: } \\
\text { Chi-square }(6)=6.2127, \\
\text { p-value }=0.3998\end{array}$} & \multicolumn{3}{|c|}{$\begin{array}{l}\text { Breusch-Pagan test: } \\
\text { Chi-square }(1)=3.766, \\
\text { P-value }=0.0523, \\
\text { Hausman test: } \\
\text { Chi-square }(4)=21.8955, \\
\text { P-value }=0.0002, \\
\\
\text { Test for normality of } \\
\text { residual: } \\
\text { Chi-square }(2)=0.7949 \\
\text { P-value }=0.6720\end{array}$} \\
\hline
\end{tabular}

***Significant at the 0.01 level (2-tailed), ** Significant at the 0.05 level (2-tailed), * Significant at the 0.1 level (2-tailed). Results are drawn from Gretl-Statistical Software.

The results from the pooled OLS model indicate that the value of $\mathrm{R}^{2}$ and adjusted $\mathrm{R}^{2}$ are 0.6454 and 0.5996 respectively. The overall explanatory power of the regression model looks good with $\mathrm{R}^{2}$ of 0.6454 . The result implies that about $64.54 \%$ change in lending rate is explained by the variations in explanatory variables, denoting that the regression has good fit and is reliable. In the model, F statistics is 14.1034 and its p-value $\left(\mathrm{F}_{\mathrm{Sig}}\right)$ is 0.000 , which signify that the model is fairly fitted well statistically. Because, the F-statistic, a measure of the overall significance of the regression, shows that the explanatory variables employed are significant at the $1 \%$ level, which is supported by low standard error of regression equation signifying minimized sum of squared error.

As a test of the presence of multicollinearity among independent variables in the model, the variance inflation factors (VIF) have been calculated. The variance inflation factors (VIF) show a value less than 1.6 for each variable. The larger the value of VIF, the more troublesome or collinear the variables and as a rule of thumb a VIF greater than 10 is unacceptable (Gujarati, 2004). The VIF less than 1.6 for each variable indicates the non- 
presence of multicollinearity. Thus, the independent variables chosen for the model are not suffered from multicollinearity problem.

White's test for heteroskedasticity OLS, using 36 observations reports the test statistic: $\mathrm{TR}^{\wedge} 2=11.8052$, with $\mathrm{p}$-value $=\mathrm{P}($ chi-square $(14)>11.8052)=0.6219$. The insignificance p-value indicates that null hypothesis is accepted, meaning that homoskedasticity assumption becomes true. The general rule is that if the test statistic has a p-value below an appropriate threshold (e.g. p<0.05) then the null hypothesis of homoskedasticity is rejected and heteroskedasticity assumed. However in the current study, the pooled OLS model is not suffered with heteroskedasticity because p-value is higher than 0.05 . Distribution free Wald test for heteroskedasticity: chi-square $(6)=3.5877$, with p-value $=0.7322$ also accepts the null hypothesis that homoskedasticity assumption becomes true in the pooled OLS model, which is confirmed by insignificance p-value of the test statistic.

In order to test the autocorrelation, Durbin-Watson test has been used. The DurbinWatson statistic $=1.2672$ with $\mathrm{p}$-value $=0.0683$ indicates mild autocorrelation in the pooled OLS model. However, the mild autocorrelation in panel data set using pooled OLS model may not hamper the beta coefficients estimation. Test for differing group intercepts has been performed for fixed effect model. The null hypothesis was that the groups have a common intercept. The result of the test statistic is $F(5,26)=8.2467$ with $\mathrm{p}$-value $=\mathrm{P}(\mathrm{F}(5,26)>8.2467)=8.98294 \mathrm{e}-005$. The significance $\mathrm{p}$-value of $\mathrm{F}(5,26)$ test statistic indicates that the groups have a differing group intercepts. Meaning that fixed effect model is suggested for the data set.

The distribution free Wald test for heteroskedasticity has been performed fixed effect model. The null hypothesis was that the units have common error variances. Asymptotic test statistic: Chi-square $(6)=6.2127$, with p-value $=0.3998$ indicates that there is no heteroskedasticity because null hypothesis is accepted. Likely, DurbinWatson statistic $=1.9637$ with $\mathrm{p}$-value $=0.4744$ indicates that there is no autocorrelation problem in fixed effect model the data set.

Breusch-Pagan test has been used to test for heteroskedasticity in the randomeffects model. It is a chi-square test. It tests whether the variance of the errors from a regression is dependent on the values of the independent variables. If the test statistic has a p-value below an appropriate threshold (e.g., p < 0.05) then the null hypothesis of homoskedasticity is rejected and heteroskedasticity assumed. In such case, heteroskedasticity is present. In this study, the null hypothesis was that variance of the unit-specific error $=0$. The result of asymptotic test statistic is Chi-square $(1)=$ 
3.766 and its $p$-value $=0.0523$. The insignificant $p$-value of the test statistic indicates that null hypothesis is accepted and there is the presence of homoskedasticity in random-effects model.

The empirical finding of the pooled OLS model suggests that there is positive and statistically significant relationship between commercial bank lending interest rate and operating costs to total assets ratio. The variable is also found statistically significant with same direction of relationship with lending interest rate using other both fixed effects model and random effects model. The result is as expected and consistent with Mbao, Kapembwa, Mooka, Rasmussen and Sichalwe (2014) where they have found that operating costs has positive effect on lending rates. Moreover, the result is justified as on the reason that high operating costs are likely to include costs due to inefficiency leading to higher lending interest rate.

Profitability (ROA) is found significantly positively associated with lending rate using pooled OLS model which is significant at $5 \%$ level of significance. It is also found significant at $10 \%$ level of significance in random effect model with same direction association. However, the variable is found insignificant in fixed effect model. The result indicates that profitable commercial banks do increase lending rate in Nepalese context. This result is contrary to priori expectation and is also inconsistent to Mbao, Kapembwa, Mooka, Rasmussen and Sichalwe (2014), where they found negative association between lending rates and profitability (ROA). The possible reason of such contrary result could be justified on ground that Nepalese commercial banks with high profitability (ROA) charge higher interest rate on their loans and advances.

Default risk seems insignificant in pooled OLS model and random effect model in explaining the lending interest rate. However, the result of fixed effects model reveals that the coefficient of default risk (non-performing loans ratio) is positive and it is statistically significant at $10 \%$ level of significance. It implies that an increase in the share of bad loans in the total loan portfolio does significantly increase in lending rates of Nepalese commercial banks.

The deposit rate, as a cost of the basic sources of financing of bank activities, is found statistically insignificant in three models used in the current study. The results indicate that deposit interest rate seems weak in explaining lending interest rates. Meaning that the intensity of its effect is considerably less than what was expected. Moreover, the result the low coefficient of the deposit rate reflects the fact that it is not the only source of bank financing in Nepalese perspective. 


\section{CONCLUSION AND POLICY RECOMMENDATION}

This study has examined the determinants of lending rate of commercial banks listed in the Nepal Stock Exchange. The descriptive and causal comparative research designs have been adopted for the study. The pooled OLS model, fixed effect model and random effect model have been used to examine the determinants of lending interest rates. The panel data of 6 commercial banks over the period of 2010 to 2015 have been collected from the annual reports of the banks in sample. The dependent variable used in the study is lending rate and independent variables are: operating cost to total assets ratio, deposit interest rate, profitability (ROA), and default risk.

The estimated regression models reveal that operating costs to total assets ratio has positive and statistically significant impact on commercial bank lending rate. Profitability (ROA) is found significantly positively associated with lending rate. Moreover, default risk has significant and positive impact on lending interest rate. However, deposit rate seems weak in explaining the variation of lending interest rate. Eventually, this study concludes that the major determinants of commercial banks' lending rate are operating costs to total assets ratio, profitability and default risk in Nepalese context.

This study offers the following recommendations based on the findings from the empirical analysis. Firstly, Nepalese commercial banks have excessive levels of lending rate which can pose a significant threat to an institution's earnings and capital base. Banks should try as much as possible to strike a balance which will help them to cover cost associated with lending and at the same time, maintain good banking relationship with their borrowers. Bank management should maintain lending rate at prudent levels which is essential to the safety and soundness of banking institution. Moreover, bank management should ensure that appropriate policies procedures, management information systems and internal controls to maintain lending rate at prudent levels with consistency and continuity.

Secondly, there is need to strengthen bank lending rate policy through effective and efficient regulation and supervisory framework. Commercial banks should develop credit procedures, policies and improve analytical capabilities of loans by which overall credit management could be effective to reduce non-performing loans and enhance their profitability. Moreover, commercial banks should avoid giving out loans that will lead to bad debt. Finally, there is a need for the government to provide essential infra-structural support to both lenders and borrowers. The research results also point to the view that the banks should improve their management practices particularly in the light of the practices in other developed and developing countries. 
Acknowledgement: The author would like to thank Madhav Prasad Dahal, associate professor of economics, for his helpful comments and suggestions.

\section{References}

Baltagi, B. H., Bresson, G., \& Pirotte, A. (2003). Fixed effects, random effects or Hausman -Taylor? A pretest estimator. Economics Letters, 79, 361-369.

Chirwa, E.W., \& Mlachila, M. (2004). Financial reforms and interest rate spreads in the commercial banking system in Malawi. IMF Staff Papers,51(1), 96-122.

Chodechai, S. (2004).Determinants of bank lending in Thailand: An empirical examination for the years 1992-1996. New York: Frankfurt am Main. Peter Lang.

Cihak, M. (2004).The determinants of lending rates and domestic spreads in Croatia. In Republic of Croatia: Selected Issues and Statistical Appendix. IMF Country Report No.04/251.

Cottrell, A., \& Lucchetti, R. J. (2011). Gretl user's guide: Gnu regression, econometrics and time-series Library. Available at http://gretl.sourceforge.net/manual.pdf

Cottrell, A., \& Lucchetti, R. J. (2017). Gretl user's guide: gnu regression, econometrics and time-series library. Available at http://www.gnu.org/licenses/fdl.html

Diebold, F., \& Sharpe, S. (1990). Post-deregulation bank deposit rate pricing: The multivariate dynamics. Journal of Business \& Economic Statistics, 8, 281-293.

Gambacorta, L. (2008). How do banks set interest rates? European Economic Review, 52, 792-819.

Georgievska, L., Kabashi, R., Manova-Trajkovska, N., Mitreska, A., \& Vaskov, M. (2011). Determinants of lending interest rates and interest rate spreads. Special Conference Paper, Bank of Greece.

Greene, W. H. (2007). Econometric Analysis. Upper Saddle River, New Jersey: Pearson Prentice Hall.

Grenade, K. H. I. (2007). Determinants of commercial banks interest rate spreads: some empirical evidence from the eastern Caribbean currency union. Eastern Caribbean Central Bank Staff Research Paper, No. WP/ 07/01.

Gujarati, D. (2004). Basic econometrics. New York: The McGraw Hill.

Hutchison, D. (1995). Retail bank deposit pricing: an inter-temporal asset pricing approach. Journal of Money, Credit and Banking, 27, 217-231.

Irungu, P.N. (2013). The effect of interest rate spread on financial performance of commercial banks in Kenya (Unpublished Master's Thesis). University of Nairobi, Nairobi, Kenya. 
Kaymaz, O., \& Kaymaz, O. (2011).Using deposit interest rates in setting loan interest rates: Evidence from Turkey. The International Journal of Business and Finance Research, 5(3), 45-53.

Matemilola, B.T., Bany-Ariffin, A.N., \& Muhtar, F.E. (2015). The impact of monetary policy on bank lending rate in South Africa. Borsa Istanbul Review, 15(1), 5359.

Mbao, F.Z., Kapembwa, C., Mooka, O., Rasmussen, T., \& Sichalwe, J. (2014). Determinants of bank lending rates in Zambia: A balance sheet approach. (Working Paper, WP/02)

Mujeri, M.K., \& Younus, S. (2009). An analysis of interest rate spread in the banking sector in Bangladesh. The Bangladesh Development Studies, 32(4), 1-33.

Olokoyo, F.O. (2011).Determinants of commercial banks' lending behaviour in Nigeria. International Journal of Financial Research, 2(2), 61-62.

Onuonga, S.M. (2014). The analysis of profitability of Kenya's top six commercial banks: internal factor analysis. American International Journal of Social Science, 3(5), 94-103.

Rose, P.S. (2003). The determinants of interest rates: Competing ideas. In Capital markets: Financial institutions and instruments in a global marketplace ( $8^{\text {th }}$ ed.).McGraw Hill/Irwin.

Schnitzel, P. (1986). Do deposit rates cause mortgage loan rates? The evidence from causality tests. Real Estate Economics, 14(3), 448-464.

Sheriff, I. M. \& Amoako, G. K. (2014). Macroeconomic Determinants of Interest Rate Spread in Ghana: Evidence from ARDL Modeling Approach. Journal of Finance and Bank Management, 2(2), 115-132.

Siddique, M.A. (2012). Towards determination of interest spread of commercial banks: empirical evidences from Pakistan. African Journal of Business Management, 6(5), 1851-1862.

Simpasa, A. M., Nandwa, B., \& Nabassaga, T. (2014). Bank lending channel and monetary policy transmission mechanism in Zambia: evidence from bank-level data. African Development Bank, unpublished manuscript.

Thompson, M.A. (2006). Asymmetric adjustment in the prime lending-deposit rate spread. Review of Financial Economics, 15(4), 323-329.

Were, M. \& Wambua, J. (2013).Assessing the determinants of interest rate spread of commercial banks in Kenya: an empirical investigation.(KBA Centre for Research on Financial Markets and Policy Working Paper Series, WPS/01/13). Accessed from http://www.kba.co.ke/downloads/Working_Paper_WPS_04_12[2].pdf 